Z. vergl. Physiologie 69, 225—248 (1970)

(C) by Springer-Verlag 1970

\title{
Further Studies on Mouthpart Receptors in Decapoda Crustacea
}

\author{
M. Moulins, M. R. Dando, and M. S. Laverack*** \\ Gatty Marine Laboratory and Department of Natural History, \\ University of St. Andrews
}

Received June 2, 1970

Summary. In the lobster Homarus gammarus (L.) (=- Homarus vulgaris M. Ed.) three bilateral groups of proprioceptors are arranged around the mouth. These strand receptor organs, termed Mouthpart Receptors (MPRs) 1, 2 and 3, were described previously and their physiological responses, mainly to mandibular movements, were characterised (Laverack and Dando, 1968).

The receptor organs are described here for Panulirus argus Latr., Nephrops norvegicus L. and Astacus leptodactylus Esch.. Because of the anatomical differences between the receptors in Panulirus and Homarus the physiological work on Panulirus was designed to characterise the responses of the receptor neurones in some detail. The input from the receptors studied was similar to that of the Homarus receptors. In Nephrops and Astacus where the anatomy is similar to that of Homarus we have demonstrated that these receptors form a non-specialised system which responds to many of the movements associated with the act of ingestion of food.

It is suggested that with other work now in progress, particularly on the innervation of the mandible (Wales and Laverack, 1970), a reasonably complete summary of the proprioceptive input associated directly with food ingestion is now possible. The relevance of this work to studies on the stomatogastric ganglia is discussed, and finally an attempt is made to compare the crustacean information with that for several insect species where the anatomy of the receptors in the mouth region is known but physiological experiments are much more difficult.

\section{Introduction}

In recent years much information on the structure and input characteristics of arthropod proprioceptors has been published (see Bullock and Horridge, 1965; Finlayson, 1968). Rarely, however, has it been possible to describe the role that such receptors play in the behaviour of the animals. One outstanding exception is the work on the crustacean abdominal MRO (Alexandrowicz, 1967) and its involvement in the control

* This work was supported partly by the Centre National de la Recherche Scientifique (Equipe de Recherche Associée No. 231).

** This represents contribution No. 487 from the Bermuda Biological Station. Work carried out in Bermuda was supported by the Science Research Council $(\mathrm{B} / \mathrm{SR} / 4866)$. 
of abdominal position (Fields, 1966; Fields, Evoy, Kennedy, 1967) yet even in this example detailed analysis of the neuronal network presents problems (Kennedy, Selverston and Remler, 1969). No doubt a large part of the difficulty involved in analysing the role of such proprioceptors is that the central events are normally located in complex large ganglia.

A useful approach is therefore to seek preparations in which the CNS component is simpler and thus more easily studied. It has become apparent that the stomatogastric nervous system of the decapod Crustacea provides one such favourable target. This system, which contains several small ganglia with a restricted number of cells, is involved in the control of foregut movements (Maynard, 1966). The interactions of the central cells in at least one of the ganglia are accessible for detailed analyses (Maynard, 1967). Several propriosensory systems innervating the foregut have now been described anatomically and physiologically. The first of the recent reports was by Larimer and Kennedy (1966) on the " $k$ " cells (Orlov, 1926a) which innervate the cardiac stomach. This was followed by work on a bilateral sensory system which innervates the oesophageal-mandibular region (Laverack and Dando, 1968) and another which innervates the gastric mill (Dando and Laverack, 1969). This paper has a twofold purpose. (1) To analyse the activity of receptors in Panulirus in which the anatomy is different to that of Homarus. (2) To analyse the role played by the MPRs in the control of movements (other than those of the mandible) associated with feeding. This second feature has been carried out on Nephrops and Astacus where the systems are anatomically similar to that of Homarus. A short report of some aspects of this work has already been published (Moulins, 1969a).

\section{Material and Methods}

Medium sized specimens of Nephrops norvegicus L. were obtained and used at St. Andrews. The work on Panulirus argus Latr., the Caribbean spiny lobster, was carried out at the Biological Station, St. George's West, Bermuda. Astacus leptodactylus Esch. was studied at the Laboratoire de Zoologie, Faculté des Sciences, Dijon, France.

The methylene blue methods described by Wales, Clarac, Dando and Laverack (1970) were used for the anatomical studies. Physiological experiments were carried out in one of two ways. In Panulirus the cephalothorax was isolated and the dorsal carapace and stomach removed down to the level of the connectives. The ventral cephalothorax was then placed ventral side down in the experimental dish, and further simple dissection was earried out to reveal the sense organs. This was similar to a type A preparation used in previous work (Laverack and Dando, 1968). A type A preparation was also used for Nephrops and Astacus, but more often the isolated thorax was split longitudinally at a position slightly lateral to the oesophagus. That side in which the oesophagus remained intact was then placed so that the oesophagus could be approached from above. In such a half animal prepa- 
ration the sense organs were readily dissected though care was necessary to reveal a sufficient length of the paragnathal nerve for recording from MPR 2 and 3. Sea water at $10-15^{\circ} \mathrm{C}$ was the bathing medium in all cases, except crayfish for which an appropriate saline (van Harreveld, 1936) was used.

Conventional recording techniques were used for the electrophysiological experiments. The appropriate nerves were raised onto platinum wire electrodes into liquid paraffin floating on the saline bath. Amplification was by $\mathrm{AC}$ amplifier and display on a Tektronix 565 or 561 A oscilloscope. Stimulation movements were made with a probe on a monitored micromanipulator system (Shelton and Laverack, 1968) or with a Servomex LF51 Mlk. II waveform generator driving a pen arm. In a few experiments an alternative source of stimulation was obtained by opening and closing a tensioned pair of fine forceps by inflating and deflating a balloon between the arms. The rate of opening or closing was monitored by attaching a potentiometer to the syringe used to inflate the balloon. Photography was by means of a Nihon Kohden SP camera, or a Catograph Alvar camera.

\section{Results}

\section{A. Anatomy \\ I. Nephrops and Astacus}

The anatomy of the MPR receptors in Nephrops and Astacus is very similar to that described previously in Homarus.

The situation is summarised in Figs. 1 and 2. A bilaterally symmetrical system of connective tissue strands (main strands) extend along each side of the mouth. Three groups of sensory cells have dendrites that ramify on subsidiary elastic (receptor) strands that attach to the main strand. These three cell groups are those of the mouthpart receptors No. 1, 2 and 3 (MPR 1, 2 and 3); MPR 1 lies anteriorly and the others towards the rear of the oesophagus. MPR 1 axons join the outer labral nerve and run to the commissural ganglion via the inferior oesophageal nerve, and our present evidence suggests that the axons terminate in this ganglion. The axons of MPR 2 and 3 run into the suboesophageal ganglion via the paragnathal nerve.

\section{Panulirus}

MPR 1 is much more difficult to locate in Panulirus than in either Homarus or Nephrops. This is due to the prolongation posteriorly of the border of the cephalothorax that immediately overlays the rostral region of the main strand. This projection is stout, heavily calcified, and forms a point anteriorly. It is difficult to remove without damage to the internal structures but in cases where removal is achieved it is found that the main strand runs up into this area and inserts laterally on the walls of this point.

At about the position where the strand runs through into the anterior projection a branch of the outer labral nerve gives a small branch 


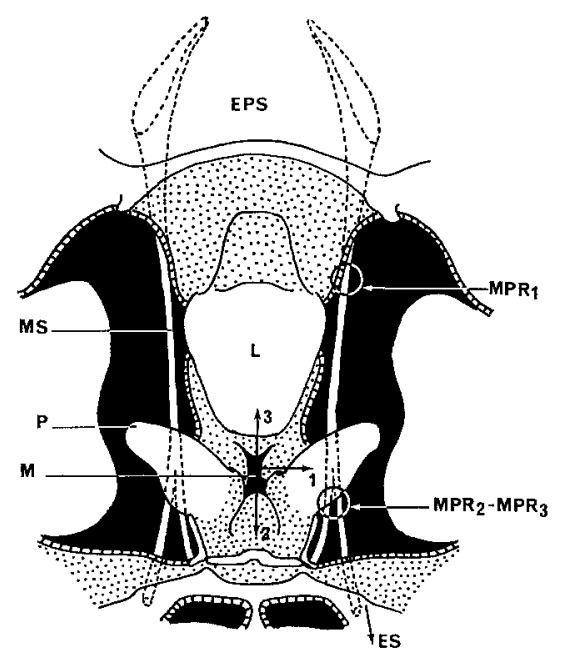

Fig. 1. A diagrammatic ventral view of the region of the mouth in Nephrops. The mandibles have been removed and the cut edges of cuticle are shown hatched. The membranous euticular regions are shown stippled. The main strand (MS) is attached to the epistome (EPS), the base of the paragnaths $(P)$ and the anterior region of the endoskeleton $(E S)$. MPR 1 lies anteriorly and $M P R 2-3$ at the posterior of the main strand. The labrum $(L)$ lies above the mouth $(M)$. The opening movements of the mouth were studied by putting mechanical pressure on the lateral walls (1), the floor (2), and the roof (3) of the orifice. (cf. Figs. 8-10)

that bears a small number of receptor cells (approximately 10). The exact position of these cells is variable and they sometimes form a cluster, at other times two separate groups, and sometimes spread diffusely in the area. They seem to be generally associated with strands of connective tissue that attach to the main strand, but also frequently to be orientated towards the labrum that lies ventral to this area. Recordings have not been attempted because of the difficulty of precise location of the axons in the unstained state, and the directionality of the stimulus.

MPR 2 on the other hand is very easy to demonstrate. The main connective tissue strand is attached along the length of the appendage as it runs across the top of the mandible. From about midway along its length and stretching as far as the rear border close to the endophragmal skeleton there is a thin sheet of connective tissue that spreads from the mandibular edge across the floor of the thorax and onto the side walls of the oesophagus. This is very thin, very flexible and quite transparent. The movements of both the mandible and the oesophagus tend to stretch the sheet in the longest axis of its construction, tangential to the long axis of the body of the animal. A stout nerve that serves this area runs 

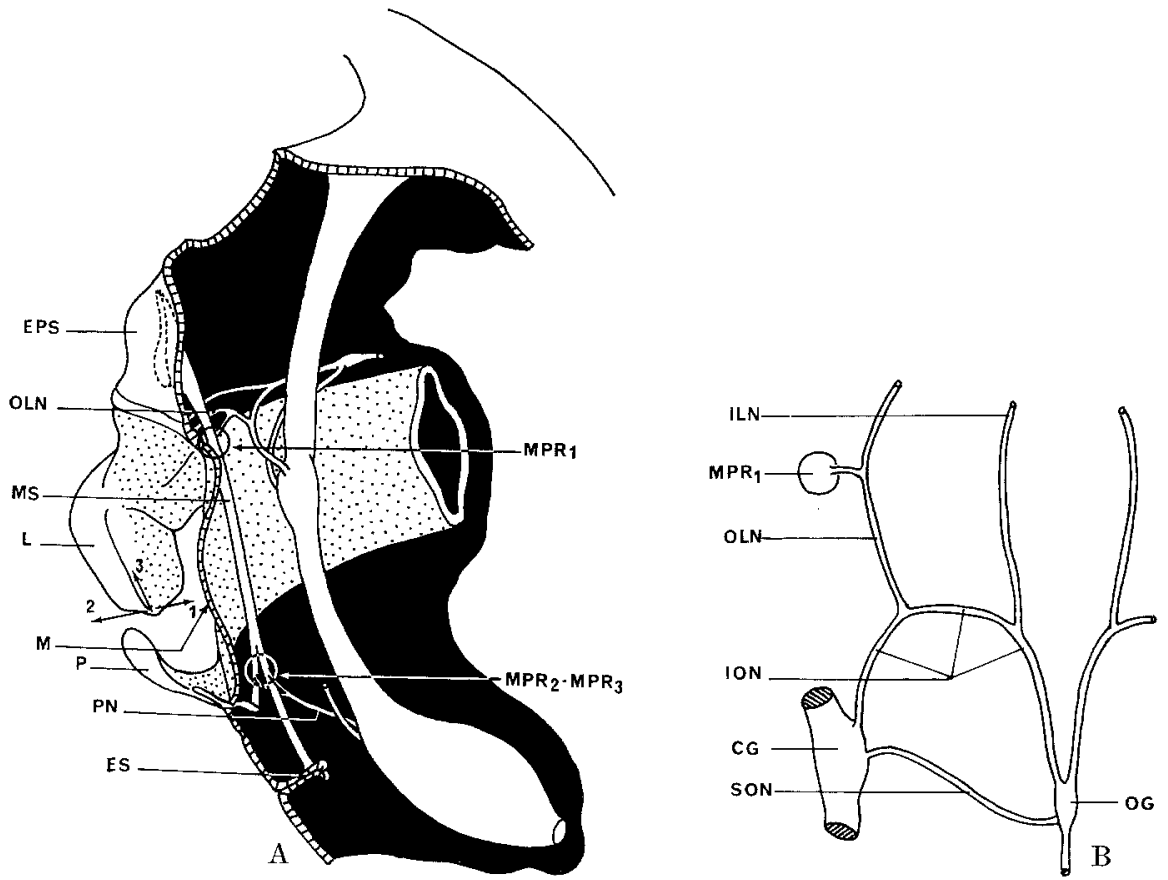

Fig. 2. A A diagrammatic lateral view of the mouth region of Nephrops after parasagittal section. 1,2,3 show the different stimulations applied to the labrum (cf. Figs. 5 -7). B A dorsal view of the left and medial part of the anterior stomatogastric nervous system, $C G$ commissural ganglion; $I L N$ inner labral nerve; $I O N$ inferior oesophageal nerve; $O G$ oesophageal ganglion; $O L N$ outer lateral nerve; $P N$ paragnathal nerve; $S O N$ superior oesophageal nerve; for the other abbreviations see Fig. 1

forward from the sub-oesophageal ganglion and splits into a number of small branches.

Of these branches one passes towards the connective tissue sheet where it further sub-divides into a group of 2 to 4 cell bodies with dendrites that continue further. The precise endings of this group of cells have not yet been traced, but the cells seem to be of bipolar form with elongate dendrites that terminate somewhere in the region of the connective tissue sheet. Of the other branches of this nerve one runs forward and diverges laterally onto the main strand as it crosses the top of the tegumental gland in this area. This nerve also contains cell bodies that are bipolar and the cells are situated on top of the main strand.

The largest group of receptor cells, however, comprise MPR 2 and are found on the sheet of connective tissue. Up to 20 cells may be observed, tending to form two groups. One of these is composed of 3 to 4 

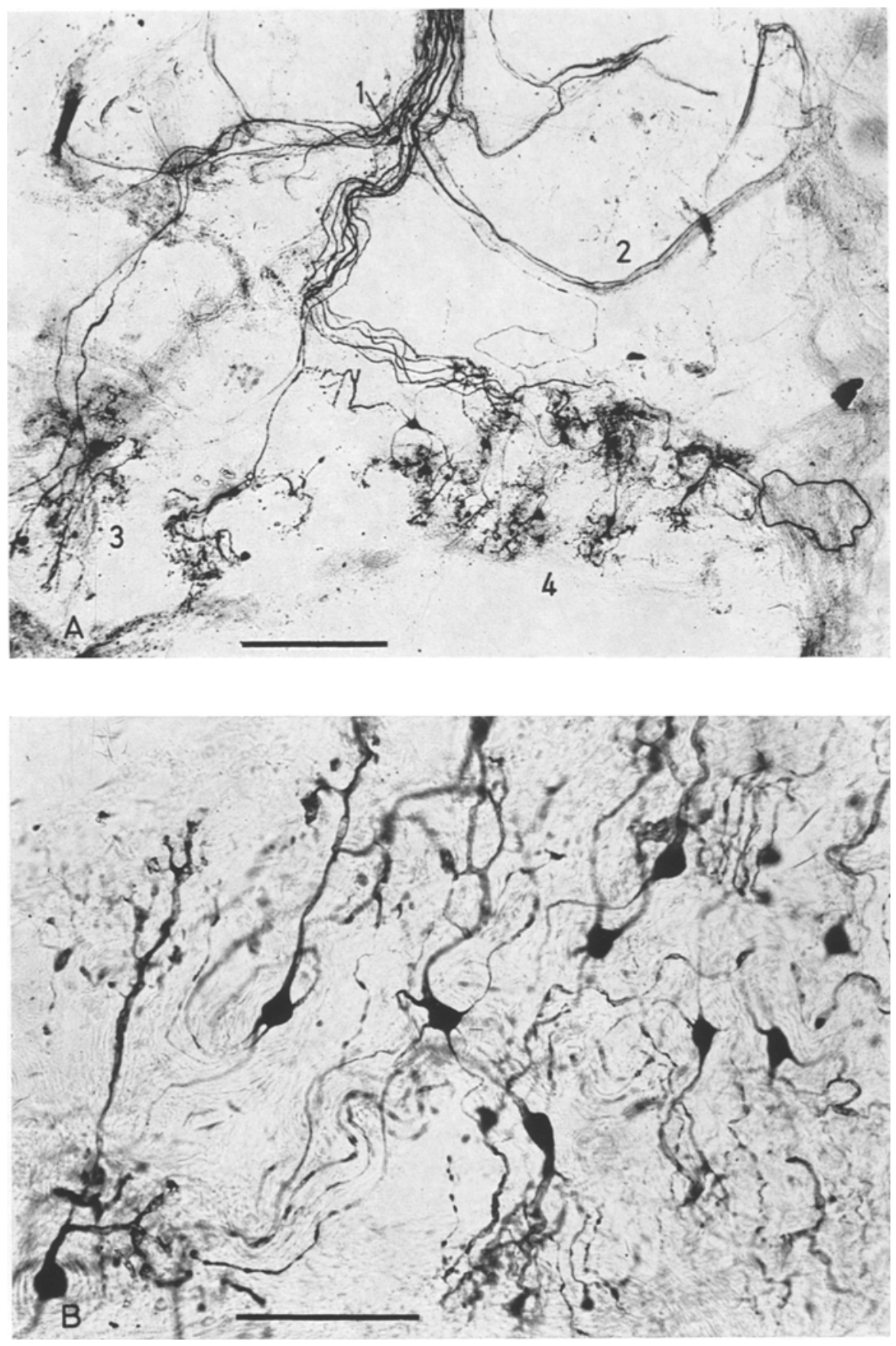

Fig. $3 \mathrm{~A}$ and $\mathrm{B}$ 
cells and lies towards the oesophageal side of the connective sheet whilst the remainder of the cells are spread evenly over the more lateral region of the sheet (Fig. 3 A). All have a similar morphology (Figs. 3 B, 4). The cell bodies are multipolar with anything up to 5 branches extending onto the connective tissue sheet. These branches radiate from the cell body and terminate in a cloud of sensory endings. In some cases (Fig. 4b) one branch extends in an opposite direction to the majority of such branches. The dendrites must be confined in a very narrow band of connective tissue due to the thinness of the connective sheet. Each dendrite ends as a small knob-shaped blunt projection. The afferent axon is of smaller diameter than the dendrites at its origin from the cell body. It broadens after about $40 \mu$ of its length and this is assumed to be the site of impulse generation.

MPR 3 is a smaller collection of cells than MPR 2. The axons form a small branch of the same major trunk but diverge at a more posterior position and run directly to the main receptor strand, at the rear of the mandible close to the insertion of the posterior adductor muscle. The nerve enters the main strand and further investigation has to include a dissection of the main strand. A small number of multipolar cells lies within the strand.

\section{B. Physiology}

\section{Nephrops and Astacus MPRs}

In a previous paper (Laverack and Dando, 1968) it was shown that in Homarus movement of the madibles, evoked either by mechanical means or by contraction of the mandibular muscles, affected the activity of the units in the mouthpart receptors. A comparative study on Nephrops and Astacus has confirmed these results and also demonstrated that the receptors monitor many of the movements in the region of the mouth and must be involved in the processes of feeding.

The movements which are important during ingestion of food are those of the labrum, the paragnaths and the walls of the mouth. These movements seem to be stereotyped although they are quite complex. We have

Fig. $3 \mathrm{~A}$ and B. Photomicrographs of methylene blue stained preparations of MPR 2 in Panulims. A A low power view to show the relationships of the innervating nerve and the receptor cells. Top of the picture is posterior, right is medial. 1, cell bodies lying in the main nerve, the terminations of the dendrites of these cells is not known. 2, lateral nerve branches going to the main strand. 3, the smaller more posterior and medial group of MPR 2 cells. 4, the more lateral larger group of MPR 2 neurones. Scale mark is $400 \mu \mathrm{m}$. B An enlargement of the cells in the major MPR 2 group to show the density and complexity of the dendritic terminations on the receptor strand. Scale mark is $100 \mu \mathrm{m}$ 

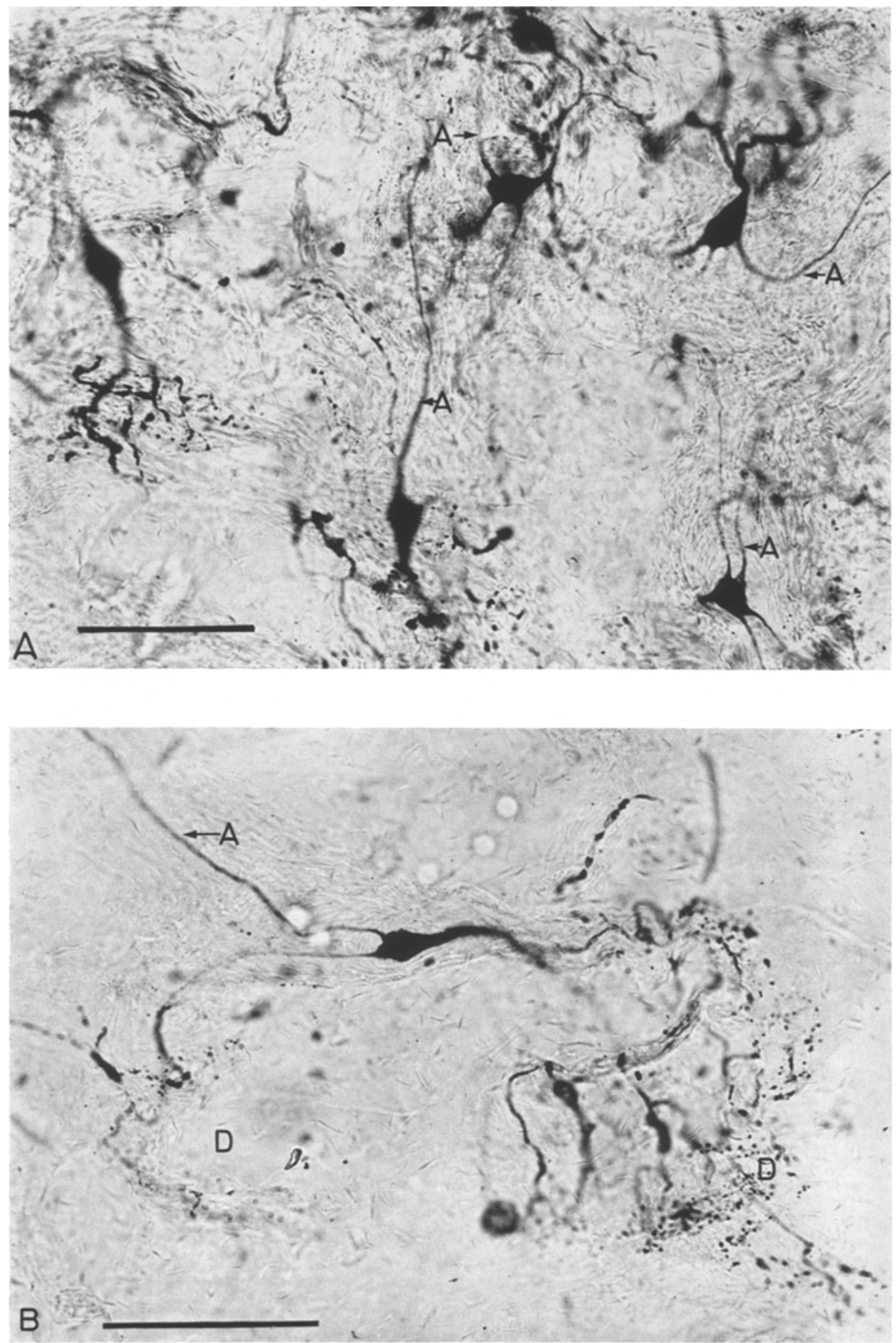

Fig, 4A and $\mathrm{B}$ 
attempted to determine the effect of movements of all these structures on the input from MPR 1 and MPR 2-3 which are considered as one receptor in this sub-section.

The resting activity which was recorded in the cut peripheral end of the outer lateral nerve (OLN, Fig. 2) is characterised by tonic units (4 in Fig. $5 \mathrm{~A}, 3$ in Fig. 14 A, 2 in Fig. $11 \mathrm{~A}, 1$ in Fig. 12 A). These units fire regularly over long periods in Nephrops and Astacus as in Homarus. The activity is certainly due to MPR 1 as it continues unchanged after section of the outer lateral nerve distal to MPR 1 (e. g. Fig. 16a). The resting activity recorded from the peripheral piece of the paragnathal nerve ( $P N$, Fig. 2$)$ is on the contrary often nil (Fig. 9) or reduced to a single tonic unit (Fig. 6 and-2D). This unit belongs to MPR 2-3.

1. Monitoring of Labral Movements. The labrum is a lobe of fairly soft tegument reflected in front of the mouth at rest (Figs. 1 and 2). It is capable of diverse movements of large amplitude due to the activity of the intrinsic musculature. During feeding the labrum is periodically drawn back further towards the mouth (Type I movement, Fig. 2) or projected forward (Type 2 movement) away from the resting position which is a little in front of the mouth.

The activity of MPR 1 is modulated by movements of type 1 (Fig. $5 \mathrm{~A}$ $-\mathrm{C})$; the frequency of all the tonic units increases during the movement but the velocity of movement has no effect (compare Fig. 5B and $5 \mathrm{C}$ ). A similar response occurs for movements of type 2 (Fig. $5 \mathrm{D}-\mathrm{E}$ ), that is to say, movements away from the rest position, either forwards or towards the mouth, cause similar responses in MPR 1 and these responses are of the same sense. Another movement, (type 3, Fig. 2) a shortening of the labrum, occurs during feeding. Such movements are not superimposed on a type 2 movement, and bring about a diminution in the activity of MPR 1 (Figs. $5 \mathrm{~F}$ and 7 ). Minimal activity of MPR 1 is therefore not indicative of the rest position of the labrum. It occurs instead at the most withdrawn position.

Labral movements also modify the activity of MPR 2 and 3 (Fig. 6), but only to a small degree, for type 1 and 2 movements. Fast and slow type 2 movement invoked no phasic responses (Fig. $6 \mathrm{~A}, \mathrm{~B}$ ), but a tonically active unit increased the rate of discharge slightly. The MPR $2-3$ system is much more sensitive to movements of type 3 . Slow movements raised the impulse frequency of a tonic unit (Fig. 6D); fast

Fig. 4A and B. Photomicrographs of methylene blue stained preparations of the major group of MPR 2 neurones in Panulirus. A A detailed view of several cells to show the relationships of the axons $(A)$ to the dendrites. Scale mark is $100 \mu \mathrm{m}$. $\mathrm{B} A$ view of a single receptor cell to show the axon $(A)$ and dendrites $(D)$. Scale mark is $100 \mu \mathrm{m}$ 


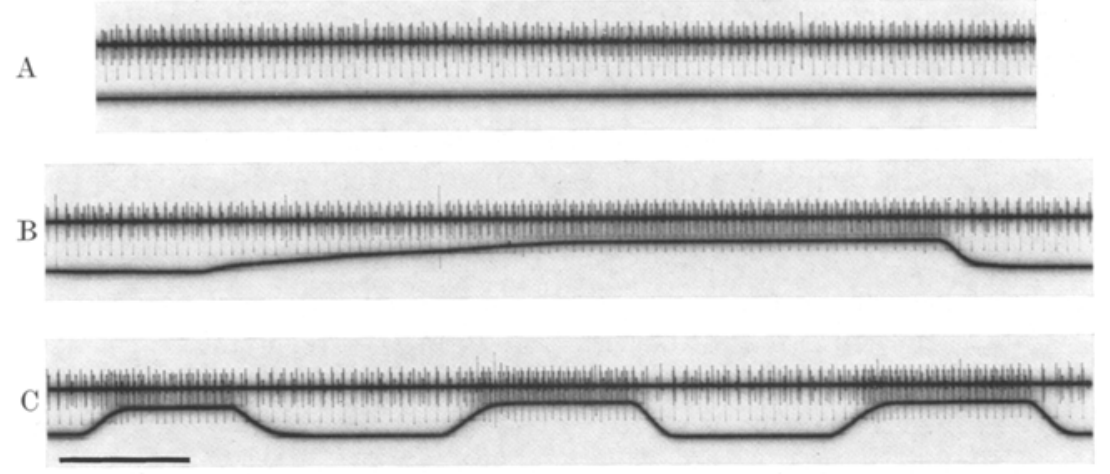

\section{D}

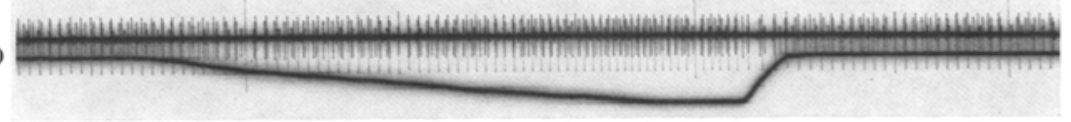

$\mathrm{E}$
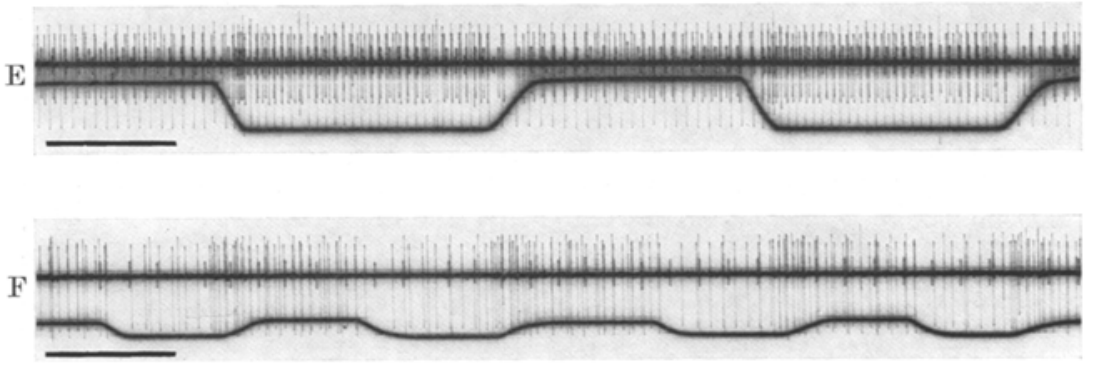

Fig. 5A-F. Recordings from MPR 1 in Nephrops during movements of the labrum. $\mathrm{A}-\mathrm{E}$ are for a single experiment but in $\mathrm{E}$ the amplification was increased for the recording electrode (top line). Lower line in each trace is a direct recording of the mechanical stimulus from the potentiometer attached to the stimulating micromanipulator. (This stimulating system applies to all the following figures unless stated otherwise.) A Resting activity. B and C Responses to posterior, type 1 movements (stimulus line up). D and $\mathrm{E}$ Responses to anterior, type 2 movements (stimulus line down). F Responses to type 3 movements (line down). Time marks for all figures are 1 sec

movements recruited a position unit (Fig. 6C) and very fast movements introduced a phasic response (Fig. 6C arrowed).

Thus for type 1 and 2 movement MPR $2-3$ respond in the same sense, but with less sensitivity than MPR 1 . MPR 1 and MPR 2-3 respond in inverse manners to withdrawal of the labrum.

2. Monitoring of Movements of the Mouth. It is possible to simulate the opening of the mouth by applying controlled deformations to the 
$\mathrm{A}$

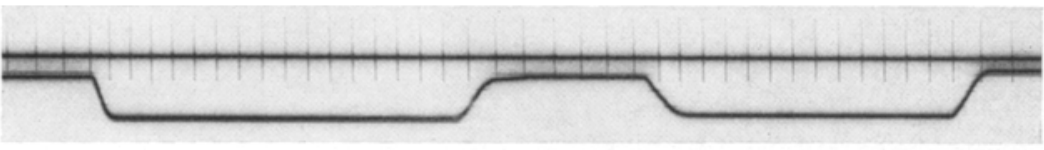

B

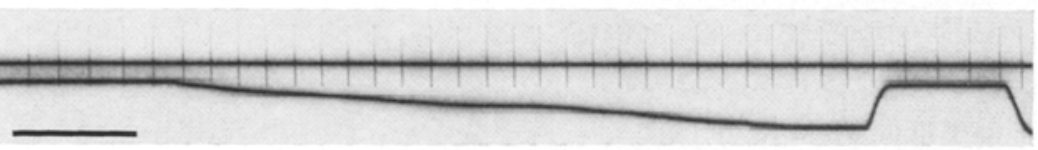

C

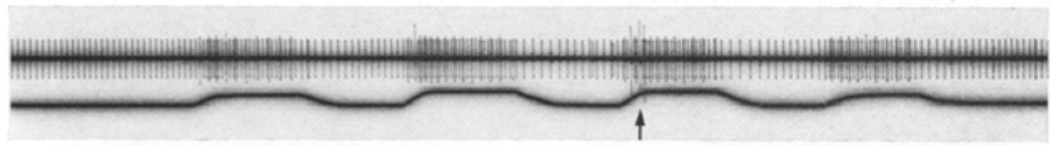

D

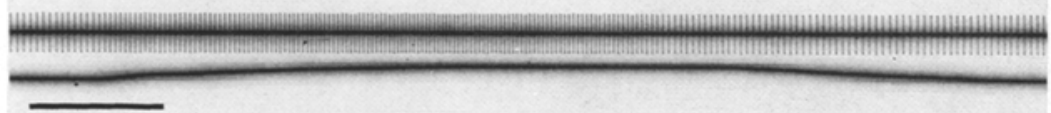

Fig. 6A-D. Recordings from MPR 2-3 in Nephrops in response to different movements of the labrum. $\mathrm{A}-\mathrm{B}$ and $\mathrm{C}-\mathrm{D}$ are for two different experiments. $\mathrm{A}$ and $\mathrm{B}$ Responses to type 2 movements (line down). $\mathrm{C}$ and $\mathrm{D}$ Responses to type 3 movements (line up). Time marks $1 \mathrm{sec}$

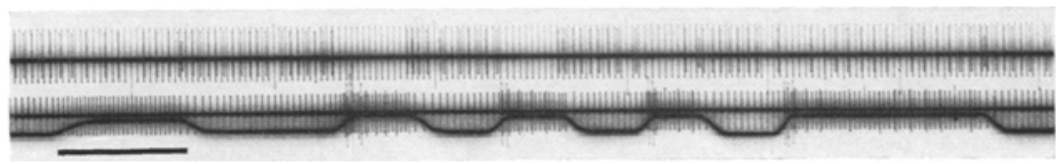

Fig. 7. Recordings of the responses of both MPR 1 and MPR $2-3$ (middle line) to type 3 movements of the labrum in Nephrops. On stimulation the lower potentiometer line moves up. Time mark 1 sec

lateral walls, the floor or the roof (movements 1, 2, 3 Fig. 1). The effects of such movements on MPR receptors was shown in a previous paper (Moulins, 1969a).

All movements bring about a considerable augmentation of output from MPR 1 (Fig. 8A for 1; 8B for 2; 8C for 3). In Fig. 8D a single tonic unit (isolated from the outer labral nerve) discharges regularly at rest. It is possible to compare the frequency of this unit with the mouth closed with that demonstrated when the mouth is open. It appears to be a position unit which, after very rapid opening of the mouth changes to a new stable frequency which is a function of the new position taken up. In common with labral movements these mouth movements do not invoke phasic responses from MPR 1 in Nephrops. 


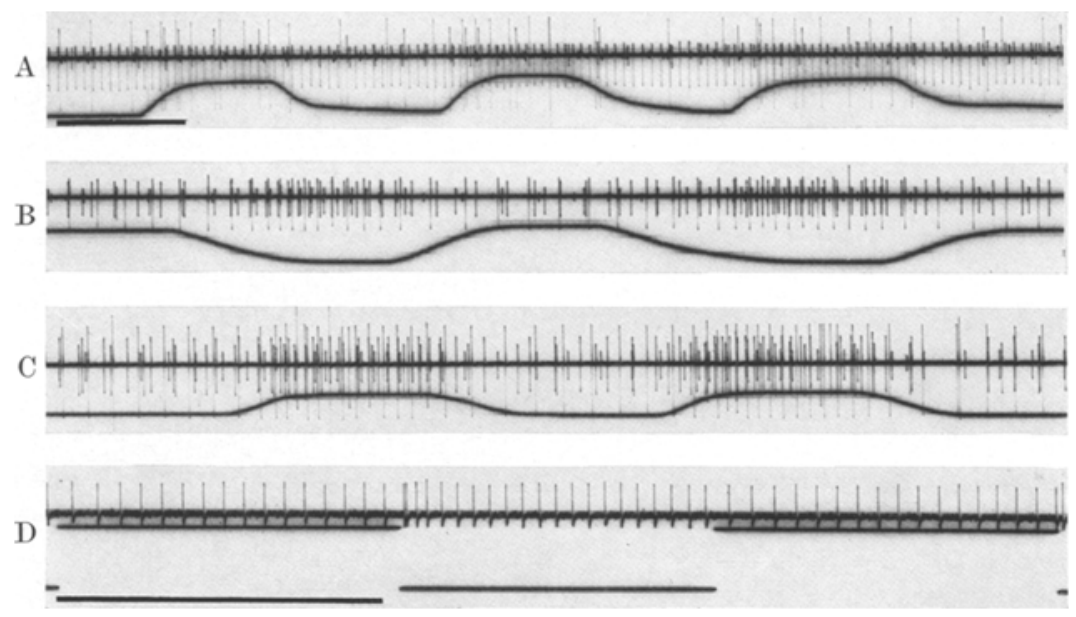

Fig. $8 \mathrm{~A}$-D. Responses of MPR 1 to various movements imposed on the buccal region of Nephrops. The four traces correspond to four different experiments though the film speed is identical for A, B and C. A Responses to movements of the lateral walls (line up). B Responses to movements of the floor (line down). C Responses to movements of the roof (line up). D Responses to rapid opening of the mouth (line down) obtained by imposing a square wave onto the floor of the buccal region via the Servomex and pen arm. Time marks 1 sec

MPR 2-3 responses differ somewhat; and there is some diserimination of directionality. Rapid movement of the lateral wall of the mouth (Fig. 9A) is monitored by activity in both fast and slow adapting units; the fast unit does not show during slow movement (Fig. 9B). The rapid adapting unit does, however, appear during even slow movements of the buccal floor (Fig. 9C).

Simultaneous recordings of MPR 1 and 2-3 (Fig. 10) show that asynchrony occurs in response to movements of the mouth. A tonic unit is found in each receptor group. Rapid movement of the buccal floor initiates an immediate response in MPR 1, but only after a delay does the MPR 2/3 discharge increase in frequency (Fig. 10 A).

This delay is an indication of the amplitude of the movement. Small deflections are insufficient to invoke phasic responses in MPR 2/3, and succeeding larger movements are required (Fig. 10B, C).

All movement of the mouth region is therefore monitored by all the MPR system, but the differential responses of the individual receptors to different movements discriminate these movements at the periphery. A slight variation was observed for Astacus. Buccal floor movement stimulated a phasic unit in MPR 1, independent of velocity of movement (Fig. 11). This type of response was never seen in Nephrops. 
A

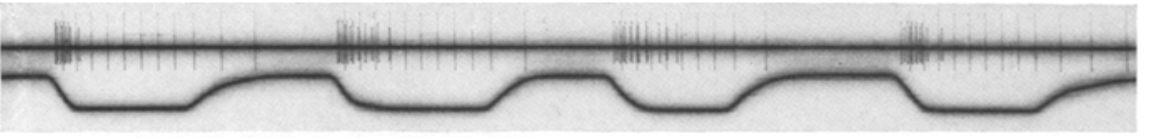

B
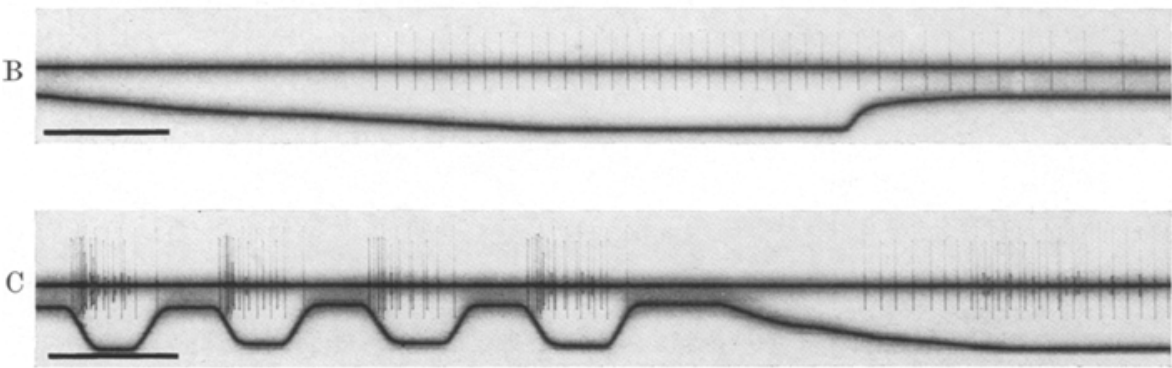

Fig. 9A-C. Responses of MPR 2-3 to various movements imposed on the buccal region of Nephrops. A and B Responses to stimulation of the lateral walls (line down).

$\mathrm{C}$ Responses to movements of the buccal floor (line down). Time marks 1 sec

A
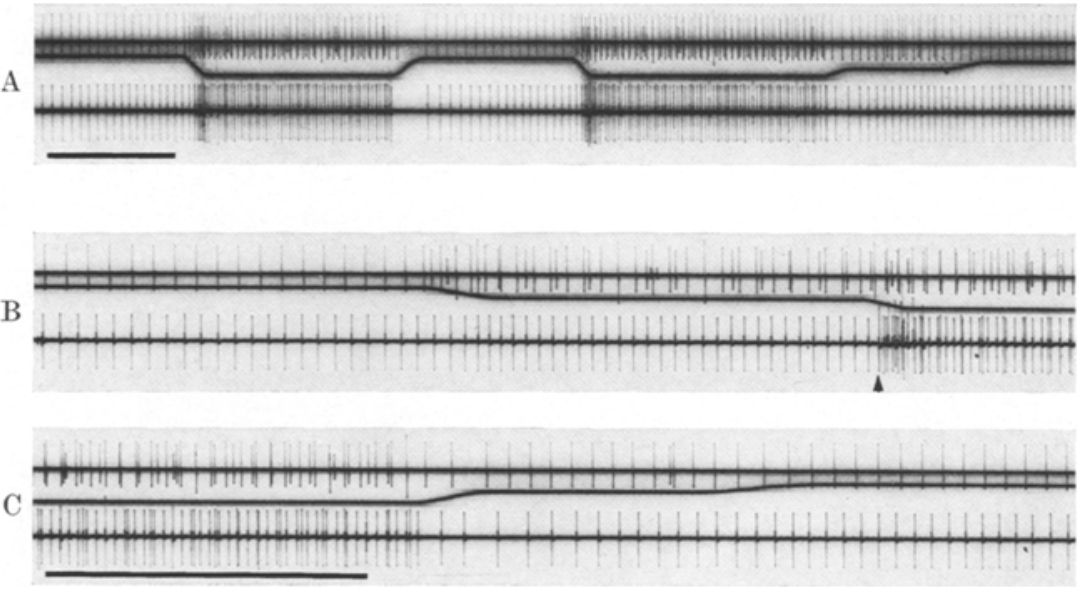

Fig. $10 \mathrm{~A}-\mathrm{C}$. Comparison of the responses of MPR 1 (top line) and MPR $2-3$ to a movement of the buccal floor of Nephrops (line down). A Stimulus in one step. $\mathrm{B}-\mathrm{C}$ These are continuous recordings and the stimulus is given in two steps (second step arrowed). Time marks 1 sec

3. Paragnathal Movements. The paragnaths are small flattened lobes situated directly behind the mouth and at rest lie behind the mandibles (Figs. 1 and 2). The paragnaths are capable of antero-posterior movements and these frequently accompany opening of the mouth by lowering of the buccal floor. 

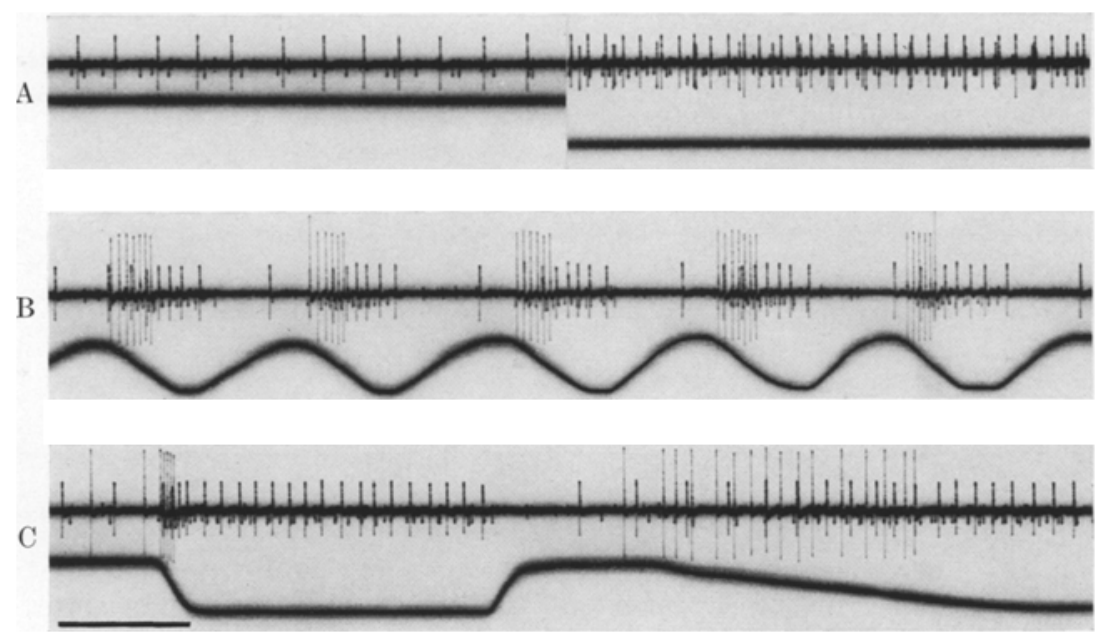

Fig. $11 \mathrm{~A}-\mathrm{C}$. Responses of MPR 1 in Nephrops to a movement of the buccal floor (line down). A The first section is with no stimulus. The second section (which is not continuous with the first) shows that after stimulation the original tonic unit has increased its frequency and new units have been brought in. $\mathrm{B}$ and $\mathrm{C}$ show that in this species MPR 1 contains phasic units. Note also the inhibition of the tonic units after the return to rest position. Time mark 1 see

Paragnath positional changes affect MPR 1 by alterations of the discharge frequency. Tonic units (Fig. 12A) increase the impulse frequency considerably when the paragnaths are moved to the rear. There is a dynamic phase to the response, which is most noticeable when movement is rapid. No phasic receptors are involved.

MPR 2-3 also respond to similar movements of the paragnath (Fig. 12D). Phasic responses occur only when rapid movement takes place. Tonic receptors also change their frequency dependent upon position. The responses of MPR 1 and MPR 2-3 recorded simultaneously show an asynchrony with MPR 1 responding more rapidly than MPR 2-3 (phasic only in Fig. 13).

In Astacus the paragnathal movements are also monitored by the MPR receptors. Resting activity in MPR 1 is increased by moving the paragnaths posteriorly. Phasic responses were not observed even when movement was rapid.

4. Oesophageal Movements. Changes in position of the wall of the oesophagus modulate the activity of MPR 1 (Fig. 14) and the response is not velocity dependent (Fig. 14A, B). The tonic unit of Fig. 14C is positionally sensitive. No phasic responses have been recorded. 
A
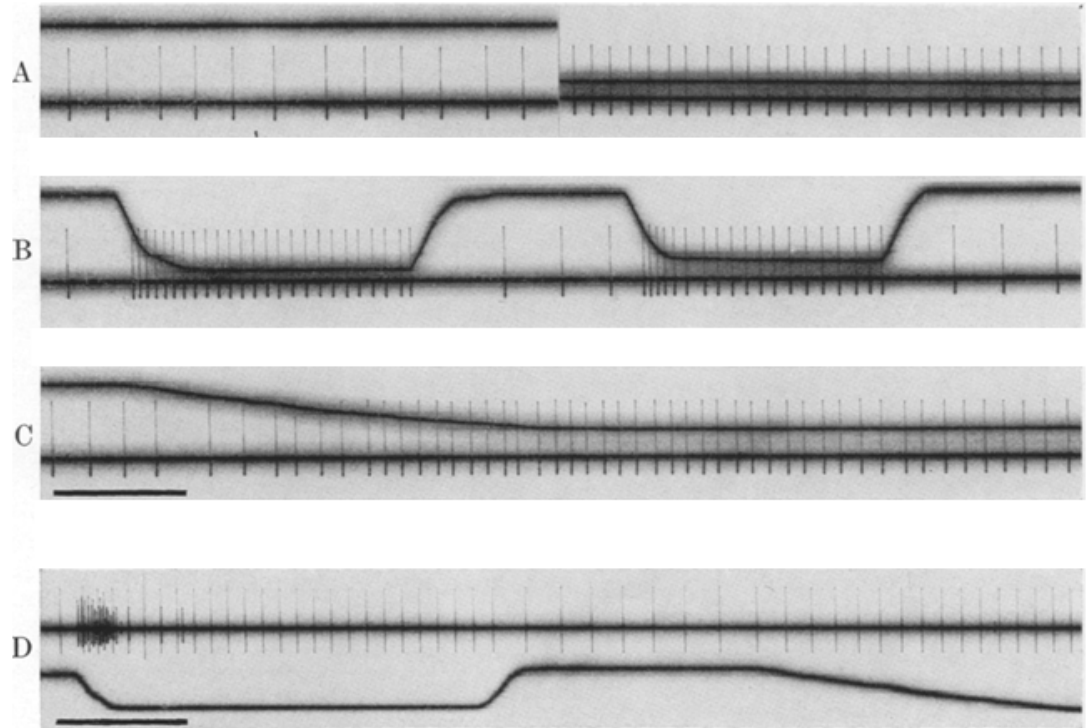

Fig. 12A-D. Responses of MPR $1(\mathrm{~A}-\mathrm{C})$ and MPR 2-3 (D) to an anteroposterior position, line up shows the paragnath in its rest position. A Discontinuous records of a single unit in rest and stimulated positions of the paragnath. $B$ and $C$ Fast and slow movements of the paragnaths bring in no other units. D MPR $2-3$ in this experiment also exhibited only a single tonic unit but a phasic response occurred when fast movements of the paragnath were made. Time marks 1 sec

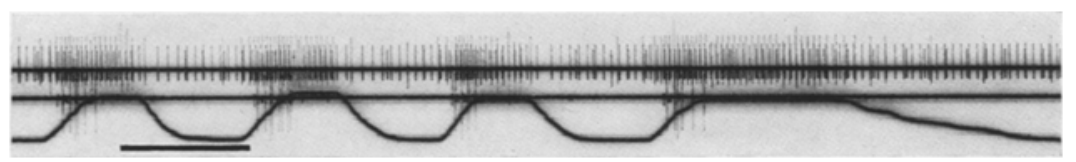

Fig. 13. Comparison of the responses of MPR 1 (top line) and MPR $2-3$ to a posterior movement imposed on the paragnaths of Nephrops (line up on stimulation). Time mark 1 sec

5. Destination of Input from MPR. Axons of MPR 2-3 run to the suboesophageal ganglion but at present we do not know if they synapse in this ganglion or merely pass through en route to another destination.

The anatomy of the area does not allow us to say if MPR 1 input passes to the commissural ganglion, the oesophageal ganglion or both. This is an important question for further studies on the system. Experiments have been carried out in which recordings have been made from various positions after section of appropriate nerve trunks (for details see Figs. 2, 15, 16). The input along these nerves indicates that it is 

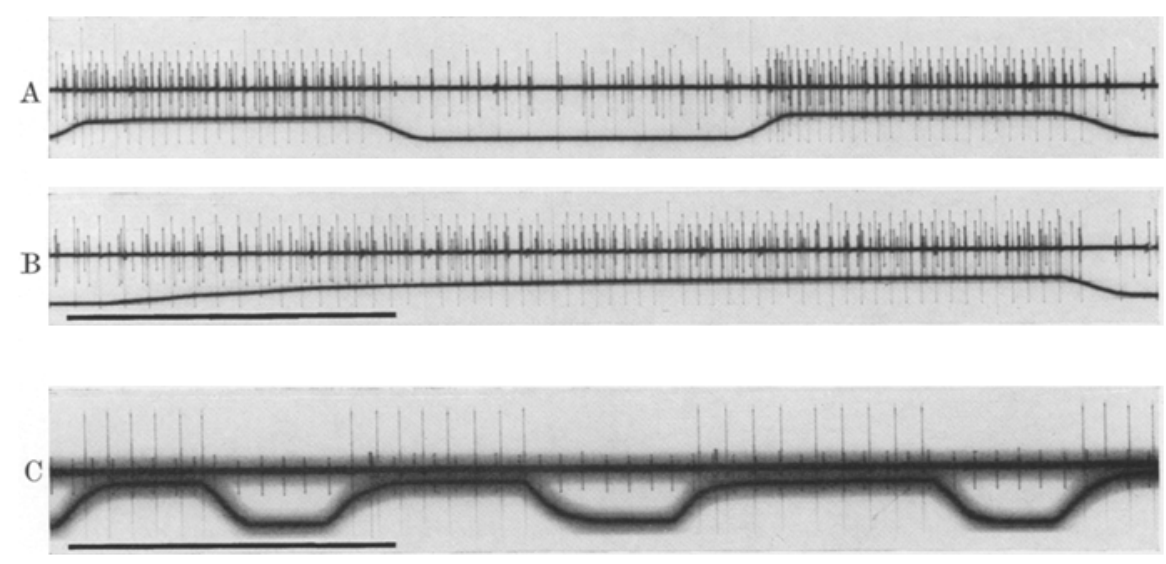

Fig. 14A-C. Responses of MPR 1 to an antero-posterior movement of the oesophagus of Nephrops (line up on stimulation). In A and B the response of the whole receptor organ is shown. In $\mathrm{C}$ the response is from one dissected unit which seems to be positional. In neither case is a phasic response seen. Time marks 1 see

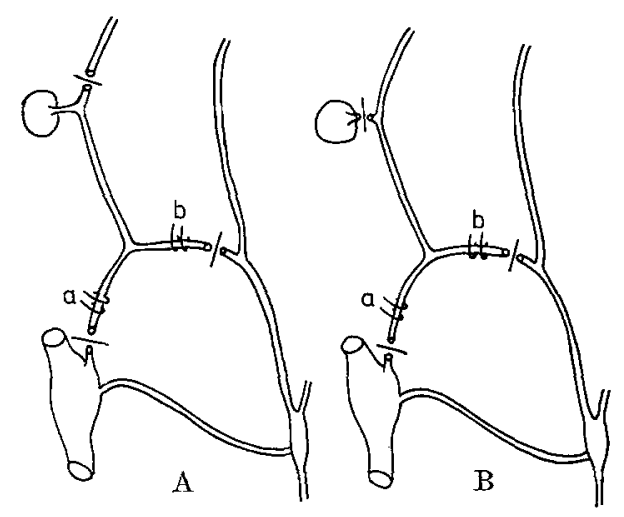

Fig. 15. Experimental conditions for the recording in Fig. $16 \mathrm{~A}(\mathrm{~A})$ and $16 \mathrm{~B}-\mathrm{C}$ (B). Refer also to Fig. 2B

the commissural ganglion that collects information from MPR 1. Other input from receptors in the labrum also pass into this ganglion via the outer labral nerve.

\section{Panulirus MPRs}

MPR 3 lies embedded in the main strand. Stretch, applied manually or by manipulator at the front end of the strand, causes firing in the organ. Usually, however, this is only in a small number of units, out 


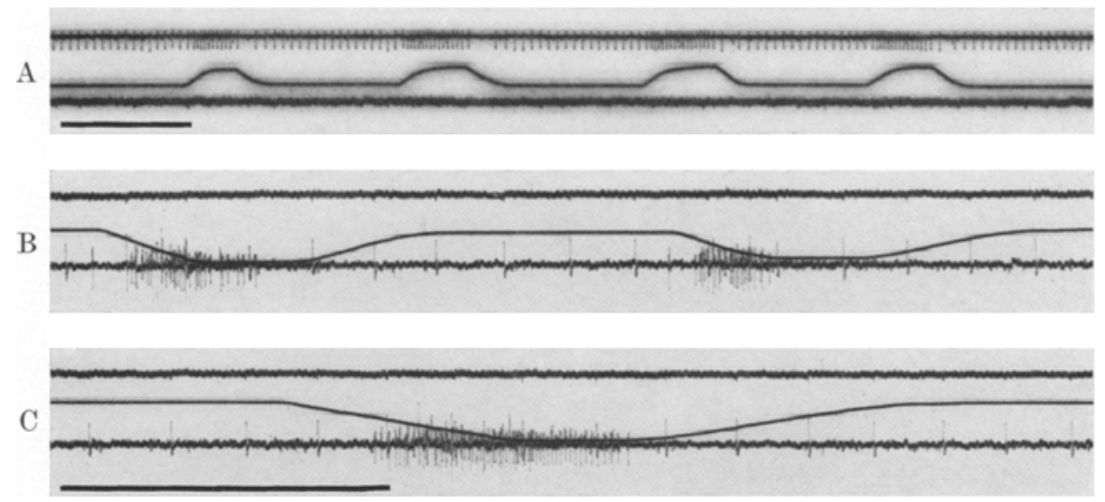

Fig. $16 \mathrm{~A}$ - C. Input pathways from the outer labral nerve. A Recordings from regions $(a)$ top line and $(b)$ bottom line of the inferior oesophageal nerve (Fig. $15 \mathrm{~A}$ ). An upward movement of the stimulation line indicates a type 1 movement of the labrum. The information from MPR 1 (here dissected to one unit) goes into the commissural ganglion. $\mathrm{B}$ and $\mathrm{C}$ The recording electrodes are positioned as in Fig. $15 \mathrm{~B}$ with $(a)$ as the bottom trace. The stimulus line going down indicates a lateral compression of the labrum caused by slight closing of tensioned forceps. Phasic and phaso-tonic units respond to this compression and this information also goes only to the commissural ganglion. Note the tonic unit which is not from MPR 1 .

Time marks 1 sec

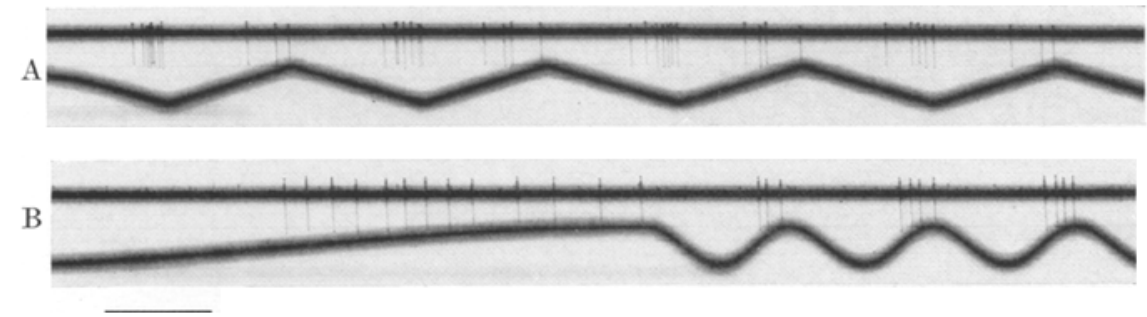

Fig. 17A and B. Recordings from MPR 3 in Panulirus in reference to stretch of the main strand. Movements were imposed via a Servomex and pen arm (bottom line). Time mark 1 sec

of the total present in the area. Fig. 17 shows the response to a variety of stimulus presentations in which the units are seen to be phasic. The degree of stretch required for firing cannot be deduced from these records, as the stimulus did not start from the fully relaxed position each time.

Recording from MPR 2 is a relatively easy process. It will be readily appreciated from Fig. $3 \mathrm{~A}$ that the connective tissue upon which the organ is situated may be deformed by stretching differentially along or across its long axis. Consequently some records show units that respond to stretch 

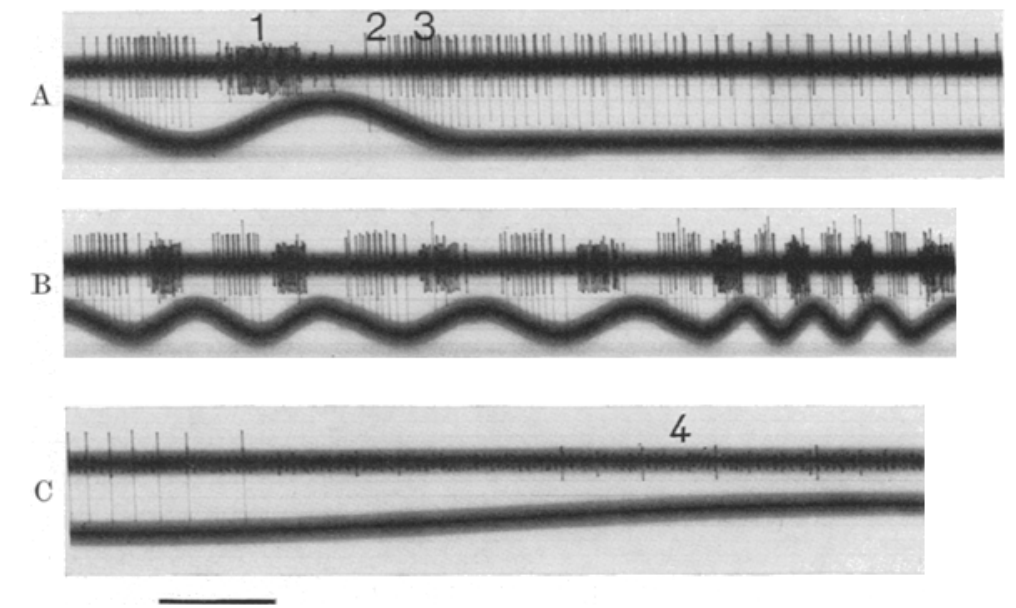

Fig. 18 A-C. Recordings from MPR 2 in Panulirus in response to stretch of the receptor sheet. The movements were imposed via a Servomex and pen arm (lower line). Numbered units are referred to in the text. Time mark 1 sec
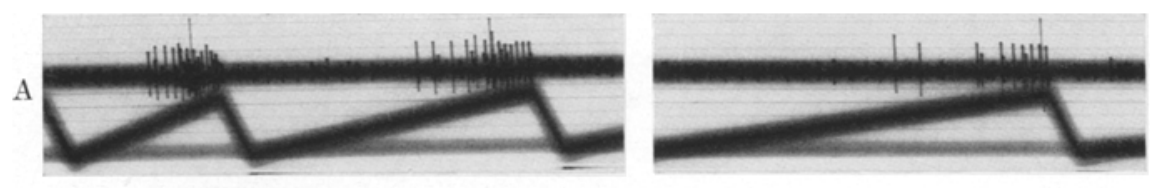

B

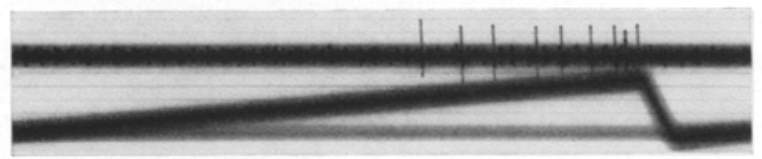

$\mathrm{C}$

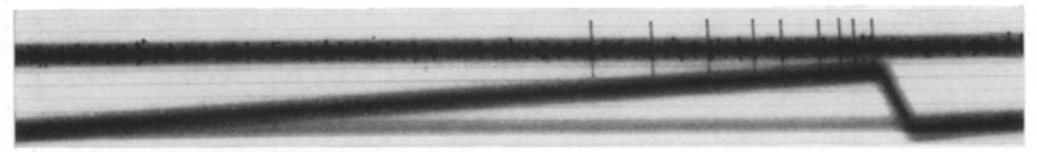

$\mathrm{D}$

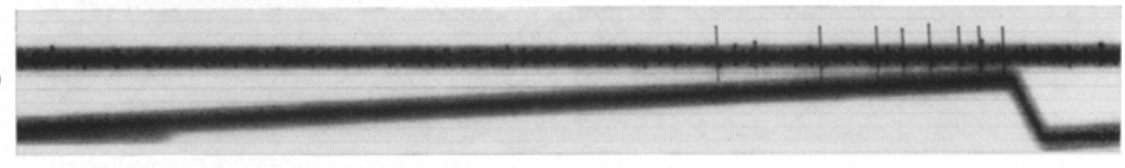

Fig. 19 A-D. Recordings from MPR 2 of Panulirus in response to constant amplitude, but varying speed, ramp functions imposed on the receptor sheet via a Servomex and pen arm. Time mark $I$ sec 

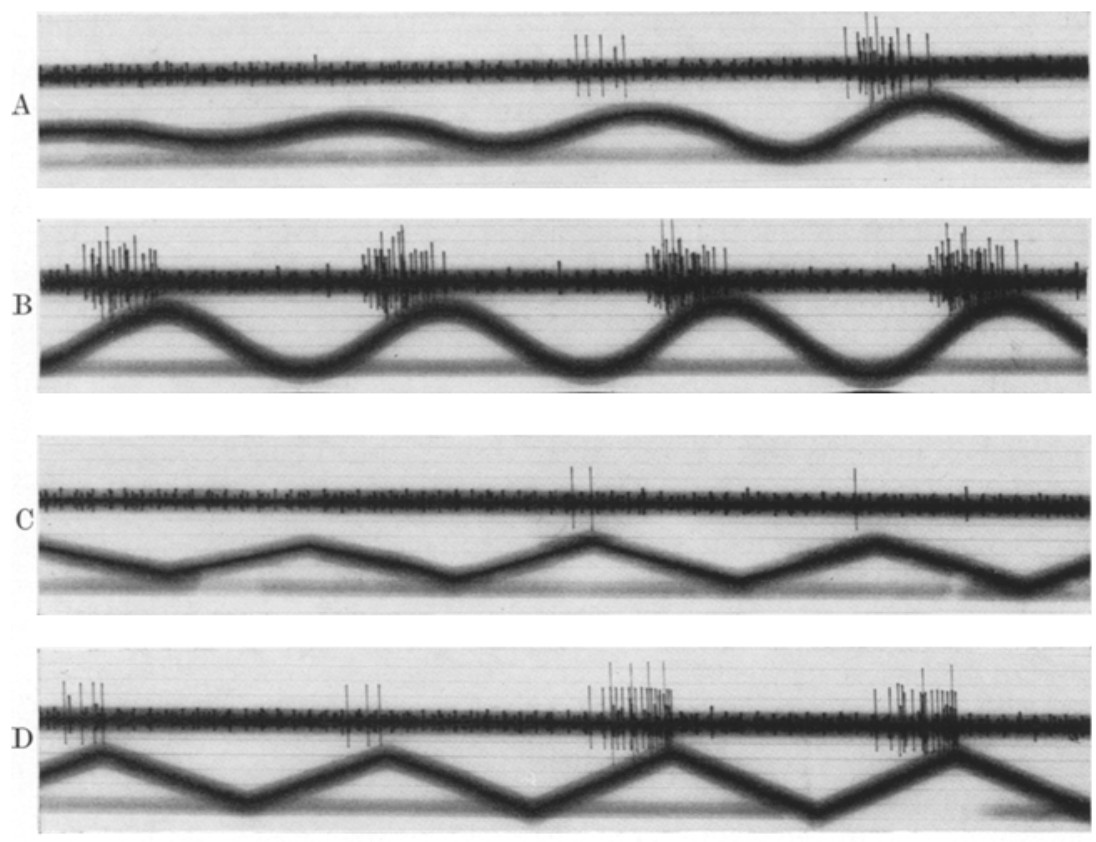

Fig. $20 \mathrm{~A}-\mathrm{D}$. Recordings from MPR 2 of Panulirus in response to ramp functions of varying amplitude imposed via a Serromex and pen arm onto the receptor sheet. Time mark 1 sec

in opposing directions. Fig. 18 shows such a case. Stretch of the connective tissue sheet demonstrates a unit (1) that is phasic and which reaches a high discharge frequency to stretch in direction 1. Stretch in the opposing direction evokes activity in two units (units 2 and 3 ), one more sensitive to position than the other since it begins to fire first, and which are velocity sensitive since with sine wave stimulation frequency rises as the acceleration increases (Fig. 18B). The first of these units is phasotonic and continues to fire with maintained stimulus, the second and smaller unit is phasic but slow adapting. At fast repetition rates unit 1 shows higher discharge rates than units 2 and 3 seem capable of attaining.

At slow repetition rates only unit 2 responds dramatically, unit 3 may fire only on maximal stretch, unit 1 does not fire at all but a further unit appears that responds to the same directionality as unit 1 (unit 4, Fig. 18C).

The firing of units in this sheet seems to relate to what are termed position fibres in the proprioceptors of leg segments. In Fig. 19 the stretch 
of the strand is imposed at varying rates in a ramp function movement. The first potential appears following the same degree of stretch in each case. The amplitude is not changed with each cycle, but the velocity of movement alters. There is little change in the response until the frequency reaches about $1: 1.5 \mathrm{sec}$ and fire faster when the terminal frequency is faster. Thus these units are sensitive to stretch, and to the rate at which stretch is imposed.

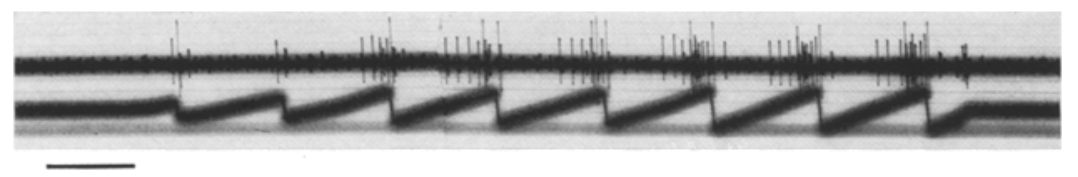

Fig. 21. Recordings from MPR 2 of Panulirus in response to other ramp functions of varying amplitude of the receptor strand imposed via a Servomex and pen arm. Time mark 1 sec

Amplitude, however, is also important as can be seen from Fig. 20. Two units are involved initially; the frequency of the smaller unit remaining about the same in each cycle, that of the larger (firing slightly after the completion of the stretch) increasing so it fires twice in each repeat period. At the greater stretch repeats a third unit is involved. Similar events take place with different waveforms and amplitudes (Fig. 21).

\section{Diseussion}

The comparative anatomy of these receptor systems enables us to make general comments upon the likely importance of such sensory information. The physiological results tend to confirm such suggestions.

It was previously suggested (Laverack and Dando, 1968) that MPR 2 in Homarus was probably more involved in monitoring oesophageal than other movements. The morphology of MPR 2 in Panulirus bears this out as it lies suspended from the oesophageal wall across to the mandible edge. Other movements undoubtedly affect the output of this organ also via the main strand, but the organ is less sensitive to such movements. By the same token MPR 3 in Panulirus responds to movement of the main strand in which the entire group of cells lies buried. MPR 1 seems to be somewhat more variable. In Homarus it is a small discrete collection associated only with the anterior part of the main strand. In Panulirus the organization of the organ is more diffuse and perhaps the distribution of dendrites and sense cells indicates the importance of labral structures in stimulation of this group. 
The number of responsive units recordable from any of these organs is always less than the number demonstrable by methylene blue staining which may also be less than the total number present in the area. It is possible that in some cases (e. g. MPR 2) cells are sensitive to parameters of movement not so far discovered. For example, some cells have their somata located in the nerve trunk that supplies MPR 2. These cells are bipolar with lengthy dendrites that extend anteriorly along connective tissue strands. Their terminations are as yet unknown. Stretch of the MPR 2 receptor sheet in Panulirus may not be adequate for stimulation. Within the MPR 2 collection of cells two distinct groupings are evident; one medially along the oesophageal wall and the other laterally near the mandibular edge. Frequently a single cell lies between these two groups with one dendritic tree disposed one way, and a second branch in the other direction (see Figs. $3 \mathrm{~A}, 4 \mathrm{~B}$ ). It is known that stretch in either direction brings about directionally specific responses and it is presumed that the organization of the dendritic trees is in some way responsible for such responses.

The receptor cells of MPR 2 seem to be unique among mechanoreceptors so far described for decapod crustacea. They are multipolar with fine dendritic branching onto a thin connective tissue sheet. In the main they are movement and velocity sensitive, giving rise to phasic responses, but occasionally units of small amplitude were noted which were not modulated by receptor strand movement. Such units may represent the activity of the supernumerary cells previously described without allocation of endings. MPR 3 consists entirely of phasic movement receptors, and are also multiterminal.

Functional studies on Nephrops and Astacus show predominantly tonic units in MPR 1 and phasic units in MPR 2--3. The conclusion that might be drawn from this is that whilst MPR 2-3 are concerned in indicating movement of the various mouth regions MPR 1 determines the final positions.

The responses of the MPR system of receptors described here and previously (Laverack and Dando, 1968) are a reflection of the insertions of the main strand of connective tissue. Any movement of mouthpart appendages that affect this strand also affects the receptors. Tension and position can be altered in many places in the system. It can be argued, therefore, that this represents a non-specific form of input regarding the positions of the mouth. Changes in the labrum, paragnath, buccal walls and mandible all affect the output from these organs.

But whilst the organs may be non-specific in that they are not limited. to one appendage positional change, they are nonetheless capable of dis- 
criminatory responses that indicate some restrictions in response. MPR 1 and MPR 2-3 constitute different functional groups, and respond differentially to different movements. They give information via different path ways to different parts of the CNS. They respond asynchronously to the same movement (Figs. 10 and 13), and they may also respond in opposing ways (Fig. 7). Such responses are allied to unidirectionality in other aspects (e.g. type 3 movements of the labrum alter MPR 2-3 activity, but not type 1 or 2 movements).

Although the sensory information fed into the CNS appears to indicate differential positions it is best to consider the whole apparatus as one entity. Loss of sensory detail has been reported for mechanoreceptor interneurone transfer (Wiersma, 1958), and this probably takes place here also. Repeated patterns of movement of mouthparts probably give rise to repeated sensory patterns that may reinforce such motor behaviour.

Each aspect of sensory input from these organs is reinforced also by further innervation of each appropriate appendage. The oesophagus (Orlov, 1926a, b), the mandible (Wales and Laverack, 1970) and the labrum (Laverack and Dando unpublished) are all heavily innervated. It is likely that the typical pattern of macruran mouth innervation is different to that of Anomura and Brachyura (where the mandible is hinged in a different fashion (Cochran, 1935)] and there are known to be variations in the MPR system (Dando, unpublished).

It should be noted that the decapod MPR system is comparable to a receptor system found in the mouth region of several insects (Moulins $1966,1969 \mathrm{~b}$ and unpublished). In contrast to the situation in decapods the Insects have a preoral cavity of which the hypopharynx forms the floor and the epipharynx the roof. In Blabera (Dictyoptera) and Forficula (Dermaptera) three connective tissue strands are stretched between the sides of the hypopharynx. In Blabera a similar strand exists in the epipharynx. The dendrites of the multiterminal receptor cells ramify on the strands. Direct recording of the activity of these cells has not yet been achieved because of the very small size of the nerve trunks involved. Nevertheless it seems very probable that these receptors function to monitor the passage of food in the preoral cavity and the mouth. It seems quite probable that they are a relatively unspecialised receptor system and that movement of several structures would be effective stimulants. Receptors in both groups run parallel to the mouth opening which is longitudinal in decapods and transverse in Insects. Many Insects have a ganglion (the ingluvial) in an analogous position to the stomatogastric ganglion of Crustacea, located on the foregut. 


\section{References}

Alexandrowicz, J. S.: Receptor organs in the thoracic and abdominal muscles of crustacea. Biol. Rev. 42, 165-287 (1967).

Bullock, T. H., Horridge, G. A.: Structure and function in the nervous systems of invertebrates, vol. 2. San Francisco: W. H. Freeman and Co. 1965.

Cochran, D. M.: The skeletal musculature of the blue crab, Callinectes sapidus Rathburn. Smithsonian Misc. coll. 92, (9) 2-76 (1935).

Dando, J., Chanussot, B., Dando, M. R.: Le système nerveuse stomodéal postcéphalique de Schistocerca gregaria Forsk. (Orthoptère et Blabera craniifer Furm. (Dictyoptère). C. R. Acad. Sci. (Paris) 267, 1852-1855 (1968).

Dando, M. R., Laverack, M. S.: Anatomy and physiology of the posterior stomach nerve in some decapod crustacea. Proc. roy. Soc. B 171, 465-482 (1969)

Fields, H. L.: Proprioceptive control of posture in the crayfish abdomen. J exp. Biol. 44, 455-468 (1966).

- Evoy, W. H., Kennedy, D.: Reflex role played by efferent control of an invertebrate stretch receptor. J. Neurophysiol. 30, 859-874 (1967).

Finlayson, L. H. : Proprioceptors in the invertebrates. Symp. Zool. Soc. 23, 217-249 (1968).

Harreveld, A. van: A physiological solution for freshwater crustaceans. Proc. Soc. exp. Biol. (N. Y.) 34, 428-432 (1936).

Kennedy, D., Selverston, A. I., Remler, M. P.: Analysis of restricted neural networks Science 164, 1488-1496 (1969).

Larimer, J. L., Kennedy, D.: Visceral afferent signals in the crayfish stomatogastric ganglion. J. exp. Biol. 44, 345-354 (1966).

Laverack, M. S., Dando, M. R.: The anatomy and physiology of mouthpart receptors in the lobster, Homarus vulgaris. Z. vergl. Physiol. 61, 176-195 (1968).

Maynard, D. M.: Integration in crustacean ganglia. Symp. Soc. exp. Biol. 20, $111-$ $149(1966)$.

- Neural co-ordination in a simple ganglion. Science 151, 531-532 (1967).

Moulins, M.: Présence d'un récepteur de tension dans l'hypopharynx de Blabera craniifer Burm. C. R. Acad. Sci. (Paris) 269, 2476-2478 (1966).

- Etude électrophysiologique des propriocepteurs controlant les movements de la bouche chez les crustacés décapodes. C. R. Acad. Sci. (Paris) 269, 1289-1292 (1969a).

- Etude anatomique de I'hypopharynx de Forficula auricularia L. (Insecte, Dermap tère): Téguments, musculature, organes sensoriels et innervations. Zool. Jb. Abt. Anat. 86, I-27 (1969b).

Orlov, J.: Die Innervation des Darmes des Flusskrebses. Z. mikr.-anat. Forsch. 4, $101-149(1926 a)$.

- Système nerveux intestinal de l'écrevisse. Bull. Inst. rech. biol. Perm. (Molotov) $5,1-21(1926 b)$.

Shelton, R. G. J., Laverack, M. S.: Observations on a redescribed crustacean cuticular sense organ. Comp. Biochem. Physiol. 25, 1049-1059 (1968).

Wales, W., Laverack, M. S.: A muscle receptor organ in the mandible of macruran decapods (Crustea). In preparation (1970). 
Wales, W., Clarac, F., Dando, M. R., Laverack, M. S.: Innervation of the receptors present at the various joints of the pereiopods and third maxilliped of Homarus gammarus L. and other macruran decapods (Crustacea). Z. vergl. Physiol. 68, 345-384 (1970).

Wiersma, C. A. G.: On the functional connections of single units in the central nervous system of the crayfish, Procambarus clarkii (Girard). J. comp. Neurol. 121, $207-235$ (1958).

Dr. M. Moulins

Laboratoire de Zoologie

Faculté des Sciences

F-21 Dijon, France
Dr. M. R. Dando

Department of Zoology

The University of Michigan

Ann Arbor, Michigan U.S.A.

Prof. Dr. M. S. Laverack

Gatty Marine Laboratory and

Department of Natural Histor

University of St. Andrews

St. Andrews, Scotland 